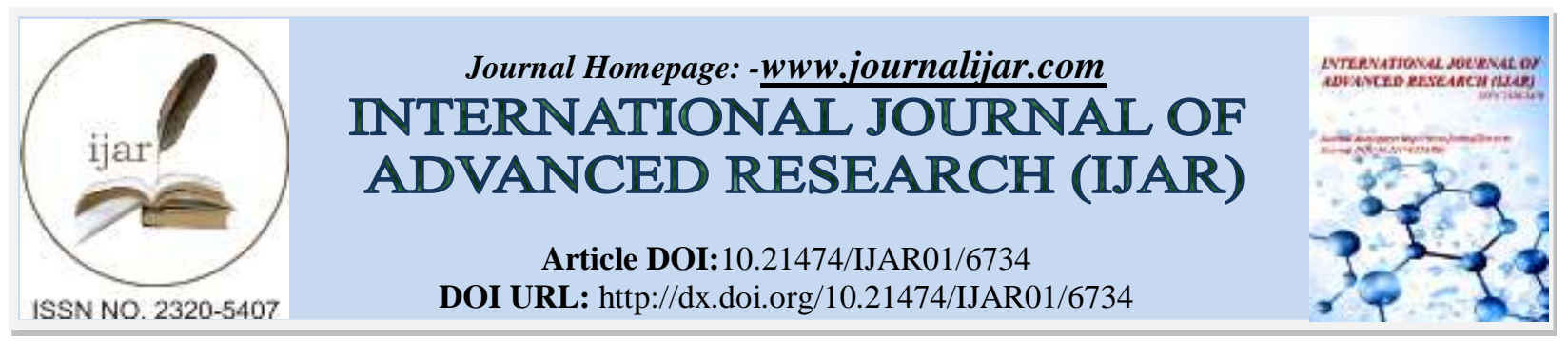

RESEARCH ARTICLE

\title{
HEAVY METALS ACCUMULATION ON COMMERCIALLY IMPORTANT MARINE EDIBLE SPECIES COLLECTED FROM LOCAL FISH MARKET, COIMBATORE, TAMILNADU, INDIA.
}

Juliyana Lebenea. A and * Chitra. G.

Department of Zoology, Nirmala College for Women (Autonomous), Coimbatore, Tamilnadu, India.

\section{Manuscript Info}

(..........................

Manuscript History

Received: 13 January 2018

Final Accepted: 15 February 2018

Published: March 2018

Keywords:-

Heavy metals, Atomic absorption spectrophotometer (AAS), fish, prawn, crab.

\begin{abstract}
The marine animals such as Lethrinus nebulosus (Vilaimeen), Sardinella longiceps (Sardine), Penaeus monodon (Tiger prawn), Fenneropenaeus indicus (Indian prawn), Portunus pelagicus (Blue crab) and Red crab (Cancer pagurus) were collected from the local whole sale fish market at Ukkadam, Coimbatore to evaluate the heavy metals accumulation in muscle tissues of selected marine edible species. The edible part that is muscle tissues of the selected fish, prawn and crab were carefully dissected for determination of seven heavy metals such as lead $(\mathrm{Pb})$, chromium $(\mathrm{Cr})$, zinc $(\mathrm{Zn})$, mercury $(\mathrm{Hg})$, molybdenum (Mo), cadmium $(\mathrm{Cd})$ and magnesium $(\mathrm{Mg})$. The level of metals accumulated were analyzed through the atomic absorption spectrophotometer (AAS).The results showed that the highest concentration of metals were recorded in prawn and crab muscles. The $\mathrm{Pb}$ and $\mathrm{Cr}$ levels were the maximum in blue crab and red crab and maximum $\mathrm{Cd}$ level was recorded in Indian prawn and tiger prawn. The lowest level of other metals like $\mathrm{Hg}, \mathrm{Mo}, \mathrm{Zn}$ and $\mathrm{Mg}$ were observed in all the muscle samples. Among all the samples, red crab and blue crab exhibited maximum accumulation of Lead (2.86 and $3.85 \mathrm{ppm}$ ) and Chromium (12.80 and 20.0ppm). Lead and cadmium are toxic and non-essential to human beings and other animals whereas chromium is non-toxic and essential to human beings but in high concentration these can be toxic. These concentrations were above the maximum level recommended by regulatory agencies and depending on daily intake by consumers, might represent a risk for human health.
\end{abstract}

Copy Right, IJAR, 2018,. All rights reserved.

\section{Introduction:-}

Marine pollution is introduction by man directly or indirectly of substances or energy to the marine environment resulting in deleterious effects such as hazards to human health, hindrance of marine activities including fishing, impairment of the quality for the use of seawater, and reduction of amenities. The pollution of the aquatic environment with heavy metals has become a worldwide problem during recent years, because they are indestructible and most of them have toxic effects on organisms (MacFarlane and Burchett, 2000). Heavy metals are defined as metallic chemical element that has a relatively high density and or poisonous at low concentration. High atomic weight metals like mercury $(\mathrm{Hg})$, lead $(\mathrm{Pb})$, arsenic (As), cadmium (Cd) and antimony (Sb) have no essential function in the body and even very low concentration can be harmful. Trace elements like ferrous $(\mathrm{Fe}), \mathrm{copper}(\mathrm{Cu})$, 
zinc $(\mathrm{Zn})$ are non-metal and lower atomic weight elements. Many of these elements are essential to the body in very low concentration but in high concentrations these can be toxic (Clark, 2001).

Marine food such as fish, prawn and crab muscle is delicious and forms an important staple part of daily food. Heavy metals entering into the fish have a possibility to get accumulated in different parts of the body and the residual amount can built up to a toxic level (Arunkumar and Hema Achuthan, 2007). The heavy metals are conservative pollutants and are effectively permanent. Fish, crab and prawn form an important link as possible transfer media to human beings. Information on the level of heavy metal pollution in coastal environment is important as they because serious environmental health hazards (Shukla et al., 2007). These levels of heavy metals accumulated by the marine animals might be due to the release of tannery effluent and electroplating manufacturing industries waste.

In this concern, the present study aimed to find the bioaccumulation of heavy metals such as lead, chromium, zinc, mercury, molybdenum, cadmium, and magnesium levels in the edible part of marine animals such as fish, crab and prawn collected from the Ukkadam fish market, Coimbatore.

\section{Materials and Methods:-} Collection of Fish Samples:-

The marine edible animals such as Lethrinus nebulosus (Vilaimeen), Sardinella longiceps (Sardine), Penaeus monodon (Tiger Prawn), Portunus pelagicus (Blue crab) and Cancer pagurus (Red crab) were collected from the whole sale fish market at Ukkadam, Coimbatore, Tamilnadu, India. The selected marine species were transported to the laboratory in an ice- cold box and stored for further analysis.

\section{Analysis of Heavy Metal Accumulation:-}

The dry ash method was used in the present study. All glassware washed with nitric acid followed by dematerialized water. The fish was dissected into muscle, using plastic knife. $5 \mathrm{~g}$ of muscle were weighed into platinum crucibles. The crucible and the test portion were placed in the Muffle furnace at a temperature of $380^{\circ} \mathrm{C}$ for 30 minutes until reaching a constant weight (grey ash). The $1 \mathrm{gm}$ of dried tissue was placed into digestion flask and concentrated nitric acid (10\%) and hydrochloric acid (5\%) were added. The digestion flask was heated to $130^{\circ} \mathrm{C}$ until all the material was dissolved. Heavy metals including essential and non- essential elements such as cadmium, chromium, lead, mercury, molybdenum, zinc and magnesium were analyzed by atomic absorption spectroscopy (AAS). Metal concentrations were calculated in micro grams per gram dry weight ( $\mu \mathrm{g} / \mathrm{g} \mathrm{d} . \mathrm{w})$.

\section{Results and Discussion:-}

Heavy metals entering the fish have a possibility to get accumulated in different parts of the body and the residual amount can build to a toxic level. The present study revealed that concentration of both essential and non-essential metals present in the marine organisms in their edible part. The concentration of heavy metals such as lead, chromium (Cr), zinc ( $\mathrm{Zn})$, mercury $(\mathrm{Hg})$, molybdenum (Mo), cadmium $(\mathrm{Cd})$ and magnesium $(\mathrm{Mg})$ in the edible part (muscle) of marine organisms such as L.nebulosus (Vilaimeen), S.longiceps (Sardine), P.monodon (Tiger Prawn), Fenneropenaeus indicus (Indian prawn), P.pelagicus (Blue crab) and Red crab (Cancer pagurus) collected from the Ukkadam fish market, Coimbatore were presented in Table-1. In this present study, highest concentration of $\mathrm{Pb}$ and $\mathrm{Cr}$ were detected in the muscle tissues of Indian prawn $(0.72$ and $2.86 \mathrm{ppm})$, tiger prawn $(0.60$ and $2.80 \mathrm{ppm})$, red crab (3.85 and $20.00 \mathrm{ppm})$ and blue crab (2.86 and $12.80 \mathrm{ppm})$. Lowest level of $\mathrm{Pb}$ and $\mathrm{Cr}$ were detected in Sardinellalongiceps and L.nebulosus fishes (0.06, 0.1 and $0.18,0.22 \mathrm{ppm}$ respectively). Lead is toxic and nonessential to human beings and other animals. Lead is used in battery castings, pipes and sheets and 43 million tons of lead produced per year. Lead used as petrol additives are largely lost to the atmosphere. This lead enters the marine ecosystem globally though rain. Coastal areas, with a lot of near shore automobile activity, can have considerably increased lead contamination (Clark, 2001). It is a cumulative toxicant that affects the multiple body systems including the neurological, haematological, gastrointestinal, cardiovascular and mental system, children's particularly vulnerable to the toxic substance to the neurotoxin effects of lead and even relatively low level of exposure can cause serious and in some cases irreversible neurological damage. These concentrations were above the maximum level recommended by regulatory agencies. Chromium is an odourless and tasteless metallic element and it is found naturally in rocks, plants, soil and volcanic dust, humans and animals. The most common forms of chromium that occur in natural waters in the environment are trivalent chromium (chromium-3), and hexavalent chromium (chromium-6). Chromium enters the environment through both natural processes and human activities. 
Waste water discharge from the agricultural related activities may be the reason for chromium contamination. Chromium is non-toxic and essential metal but in high concentration it can be toxic.

Table 1:- Concentration of heavy metals in muscle tissues of different marine species

\begin{tabular}{|c|l|c|c|c|c|c|c|c|}
\hline \multirow{2}{*}{ S.no } & & Marine & \multicolumn{2}{|c|}{ Heavy metals (ppm) } \\
\cline { 3 - 9 } & Species & Lead & Chromium & Zinc & Mercury & Molybdenum & Cadmium & Magnesium \\
\hline 1. & L.nebulosus & 0.06 & 0.18 & 3.22 & 0.037 & BDL & 0.35 & 0.096 \\
2. & S.longiceps & 0.1 & 0.22 & 3.60 & 0.16 & BDL & 0.12 & 0.164 \\
3. & P.monodon & 0.60 & 2.80 & 2.40 & BDL & 0.02 & 2.00 & 0.020 \\
4. & F.indicus & 0.72 & 2.86 & 2.20 & BDL & BDL & 1.20 & 0.024 \\
5. & P.pelagicus & 2.86 & 12.80 & BDL & BDL & BDL & 0.02 & 0.072 \\
6. & C.pagurus & 3.85 & 20.00 & BDL & BDL & BDL & 0.03 & 0.120 \\
\hline
\end{tabular}

BDL- Below detectable level (DL- Detectable level is: 0.001ppm)

Lowest concentration of mercury, molybdenum and magnesium were detected in edible part of the fishes. The Food and Agricultural Organization has determined a maximum tolerable weekly intake of $7 \mu \mathrm{g} \mathrm{Cd} / \mathrm{Kg}$ of body weight. The European Union maximum residual limit (MRL) permitted in fish is $0.1-0.3 \mu \mathrm{g} / \mathrm{g}$ for Cd. (Herreros et al., 2008). The high concentration of Cadmium was detected in the muscle tissue of tiger prawn (2.0ppm). Moderate exposure to $\mathrm{Pb}$ and $\mathrm{Cd}$ reduce human semen quality and is related to many diseases in adults and children (Telisman et al., 2000). Cadmium is widely present in the environment at low levels and is not an essential element for humans, animals and plants. Main source of Cadmium is by product of Zinc mining and Nickle- Cadmium production. High cadmium level leads to gastro intestinal disorders, kidney failure and hypertension. Cd in pregnant women has been related to reduce pregnancy length and newborn weight and recently to disorders of the endocrine and or immune system in children (Schoeters et al., 2006). The lowest level of $\mathrm{Hg}, \mathrm{Mg}$ and Mo was recorded in all the selected species than the recommended level. Even though the marine animals having below the recommended level, the frequency of intake may increases the heavy metal accumulation and leads to health effects.

\section{Conclusion:-}

The results of this study give valuable information on the bioaccumulation of toxic metals in marine edible animals. Red crab and blue crab muscle tissues exhibited maximum tendency to accumulate cadmium, lead and chromium. These concentrations were above the maximum levels recommended by regulatory agencies, and depending on daily intake by consumers, might represent a risk for human health.

\section{References:-}

1. Arunkumar,K. and Hema Achyuthan, D. (2007): Heavy metal accumulation certain marine animals along the East Coast of Chennai, Tamilnadu, India. J. Environ Biol., 28:637-643.

2. Clark, R.B. (2001): Metals-Marine Pollution. Oxford University Press, Oxford. 5:98-125.

3. Herroeros, M., Nunez, L., Sanchez-Perez, E., Encinas, T. and Gonzalez Bulnes, A. (2008): Contribution of fish consumption to heavy metals exposure in women of childbearing age from a Mediterranean country (Spain). Food and Chem Toxicol., 46:1591-1595.

4. Macfarlane, G.B. and Burchett, M.D. (2000): Cellular distribution of $\mathrm{Cu}, \mathrm{Pb}$ and $\mathrm{Zn}$ in the Grey Mangroove Avicemmia marina (Forsk). Vierh Aquatic Botanic., 68: 45 - 49.

5. Mitra.A.,Hazara S. and Chandhuri, A. (2000): Heavy Metal Concentrations in India Coastal Fishes. Res.J.Chem.Environ., 4:35-37.

6. Schoeters,G.,DenHond, E., Zuurbier, M., Naginiene, R., van den Hazel, P.,Stilianakis, N., Ronchetti R. and Koppe, J.G. (2006): Cadmium and children: exposure and health effects. Acta Paediatr Suppl., 95:50-54.

7. Shukla, Vineeta, Monika Dhankhar, Jai Prakash and K.V. Sastry (2007): Bioaccumulation of $\mathrm{Zn}, \mathrm{Cu}$ and Cd in Channa punctatus. J. Environ. Biol., 28, 395-397.

8. Telisman, S., Cvitkovic, P., Jurasovic, J., Pizent, A., Gavella, M., Rocic, B. (2000): Semen quality and reproductive endocrine function in relation to biomarkers of lead, cadmium, zinc, and copper in men. Environ Health Perspect., 108:45-53. 